\title{
Socio-economic Impacts of Intra- and Extra- Regional Southern African Development Community Migration on South Africa
}

\author{
Maurice Oscar Dassah \\ Cape Peninsula University of Technology, South Africa \\ dassahm@cput.ac.za \\ DOI//http://dx.doi.org/10.4314/gjds.v14i1.13
}

\begin{abstract}
Governance of international migration, which involves cross-border movement of people from adjoining countries and intra - and extra-regional non-adjoining countries, is currently a topical global issue. South-North and South-South are the commonest directional migratory flows; eighty percent of the latter is cross-border, a widespread phenomenon within the Southern African Development Community. Over the years, the popular view in South Africa has been that African migrants mainly negatively impact the country socio-economically. The presence of African migrants triggered two major xenophobic attacks in 2008 and 2015. The research question addressed in this article is: what are the socio-economic impacts of African migrants on South Africa? Critical in-depth analysis of literature, empirical studies and official documents indicate positive impacts co-exist with negative ones. The former include 'brain gain' from highly-qualified African academics in instruction/research positions in universities, provision of essential services by African medical personnel in the public health system, job creation and development of business skills by African small-business owners/entrepreneurs and provision of essential services by semi-skilled/unskilled African migrants to the agricultural, construction and domestic services sectors. Governance of migration informed by the country's need for 'scarce and critical skills', and entrepreneurial acumen is recommended.
\end{abstract}

Keywords: Brain Drain and Brain Gain, Development, Socio-economic Impacts, Migration, Push and Pull Factors, South Africa

\section{Introduction}

Governance of international migration is currently a topical issue, underpinned by exodus of war-affected Syrians to Europe reported to be at an unprecedented migratory scale since the Second World War, the continuing crossing of thousands of Africans across the Mediterranean Sea to Europe and the burning issue of immigration in the United States of America. International migration has four aspects: permanent 
migration, labour migration, undocumented migration and refugees (United Nations, 1982), any of which may involve movement of people from countries within the same region (intra-regional) or from other regions (extra - regional). Citing the United Nations (2000), the African Union (2006:3) estimated the number of migrants in Africa to be 16.3 million. The AU also cites the International Labour Organisation as estimating the number of labour migrants on the continent at one-fifth of the global total and that by 2025 a tenth of Africans will be living and working outside their countries of birth.

Based on the notions of global North and global South, international migration takes four main directions: North-North, North-South, South-North and South-South. 'Global North' and 'global South' came into the vocabulary of comparative study on development among nations in the early 1990s. The distinguishing indicators between North and South are politics, technology, wealth and demography (Odeh, 2010). According to the author, the global North refers to developed societies of Europe and North America, which are characterised by established democracy, wealth, technological advancement, political stability, aging population, zero population growth and dominance of world trade and politics. The global South represents mainly agrarian economies in Africa, India, China, Latin America and others that are not as economically sound and politically stable as their global North counterparts and tend to be characterised by turmoil, war, conflict, poverty, anarchy and tyranny (Odeh, 2010). In short, the global North is synonymous with development, while the global South is associated with underdevelopment.

The global South is defined in different ways. According to Blakewell (2009), the World Bank defines the global South as comprising all countries that are not 'high - income', equating the global South to less and least developed regions, while the United Nations Development Programme sees it as countries that lack a very high human development index. This means different countries belong to the global North or global South depending on which definition is adopted, which has implications for statistics used in discussing South-South migration (Global Forum on Migration and Development, 2012). Based on definitions of global North and global South, North - North migration is understood as movement of citizens of developed economies to other developed economies. Conversely, North-South migration is the movement of people from developed economies to underdeveloped economies, while South-North migration refers to movement of citizens of underdeveloped economies to developed economies and South-South migration the movement of people from underdeveloped economies to other underdeveloped economies. South-South migration, then, refers to migration among less developed regions/countries or those with 'high', 'medium' and 'low' human development index. On South-South migration, the Dutch Ministry of Foreign Affairs (2008) avers that $47 \%$ of all migrants from developing countries are in other developing 
countries and sub-Saharan Africa has the highest South-South migrants, with 67\% of international migrants. Globally, apart from emigrants from Latin America and the Caribbean, about half of emigrants move within the same continent and, with about 65\% emigrants, sub-Saharan Africa has the highest intra - continental or South-South regional emigration in the world (Ratha, Mohapatra, Ôzden, Plaza, Shaw \& Shimeless, 2011). Within Africa, Côte d'Ivoire (8\%) is the leading destination country for African emigrants, with South Africa (6\%) in second place (Ratha et al., 2011:15). The main drivers of intra-African emigration are job opportunities, arbitrary colonial borders and internal and cross-border conflicts (Ratha et al., 2011:18). Most emigration occurs across neighbouring countries; $66 \%$ of it in Southern Africa, with South Africa as the magnet (Ratha et al., 2011).

This article focuses on the socio-economic impacts of migration to South Africa of Africans from and beyond the Southern African Development Community (SADC). South-South migration has attracted the attention of the United Nations Department for Economic and Social Affairs (UNDESA), governments in the Global Forum on Migration and Development, economists and development practitioners, and the United Nations Development Programme (UNDP) and is as important as South-North migration (International Organisation for Migration, 2013).

Regarding migration to South Africa, Census 2001 indicated that the population of foreign-born persons (permanent residents/immigrants, temporary residents/work permit holders and contract workers) was 1025072 or2.3\% of the total population of which 22\% (225 515) were European, 67\% (687 678) originated from neighbouring SADC countries, $4 \%$ were born in the rest of Africa (41 817) and 4\% (40 889) had Asian origin. According to Census 2006, 2.4\% of the population (958 186) and was foreign-born (Maja and Nakanyane, 2007:7). Census 2011 found 3.3\% of the population (1.7 million out of 51.7) was non-South African, with Zimbabwe (60 5418), Mozambique (37 7021), Lesotho (14 2694), Swaziland (33 151), Zambia (27 163), Congo (25, 578), Nigeria (23 757) and Democratic Republic of Congo (22 538) among the top eight migrant-producing African countries. No reliable figures exist for undocumented ('illegal') migrants, most of who are believed to be from Mozambique, Lesotho and Zimbabwe and tend to work in the construction, services and commercial farming, and informal trading sectors.

Following this introduction, the rest of the article is organised into four sections. Section one examines various hypotheses and theories on migration, which is essential for holistic understanding of this phenomenon. Section two analyses previous empirical studies and official documents to ascertain South Africans' attitudes towards migrants and migration, while Section three identifies negative and positive socio-economic impacts African migrants have on South Africa. Given the current shortage of 'scarce and 
critical skills', section four provides recommendations on governance of migration to facilitate the country's development.

\section{Hypotheses and Theories on Migration}

A comprehensive coverage of hypotheses and theories on migration is essential to provide holistic understanding of the global phenomenon of migration. The sections that follow examine various hypotheses and theories.

\section{Neoclassical Economics and 'Push-pull' Factor Theory}

The earliest theory on migration was Ravenstein's 'laws of migration' (1885, 1889), which were "not really laws but empirical generalisations" (King, 2012:12) based on British censuses. Although these 'laws' are more applicable to internal migration, they became the cornerstone of thinking on migration and hypotheses for theorising and researching migration. Together with rational choice theory and rural-urban development, the 'laws of migration' are reflected in the 'push-pull' theory (King, 2012).

The neoclassical economic theory holds that skills are uniformly distributed in sending and destination countries/regions (Haas, 2010). It assumes that, as rational beings, prospective migrants obtain information and conduct cost-benefit analyses before going where they would be most productive and stand the chance to earn higher wages. This explains why countries with higher wages attract or pull migrants from countries where wages are low.

While the neoclassical theory is logical and simple (Malmberg, 1997), it is said to be unworkable because of its deterministic, functionalist and ahistorical stance. It does not explain "first, why so few people actually migrate, despite the apparent incentives to do so; and second, why some countries have high rates of out-migration whilst others, with the same structural economic conditions, have very low rates" (King, 2012:14). Other shortcomings are its failure:

... to consider personal, family or socio-cultural factors; to acknowledge a political reality of multiple barriers to international movement; to pay attention to the varied histories of colonialism that linked certain countries together and not others; and to take on board the systemic structuring of the world economy in terms of dependency and underdevelopment (King, 2012:14).

Ravenstein's 'laws of migration' and rational choice theory are reflected in the 'push pull' theory (King, 2012). 


\section{'Push-pull' Factor Theory}

Proponents of the 'pull-push' factor theory (Massey, Arango, Hugo, Kouaouci, Pellegrino and Taylor, 1993; Rystad, 1992; Zinyama, 1990; Zopf, 1984) postulate that, on the one hand, certain disadvantages or prevailing conditions (push factors) in sending countries, such as relatively low wage levels, poverty, lack of employment opportunities, rapid population growth, political instability or unrests and lack of or poor social amenities such as roads, piped water and electricity, compel people to migrate. On the other hand, advantages (pull factors) in destination or receiving countries such as higher wages, better employment opportunities/prospects, political stability and freedom, better education and welfare, and better social amenities attract pull people towards those countries. The theory neither suggests sending countries have no advantages at all nor that receiving countries have no disadvantages. 'Push' and 'pull' factors exist in both sending and receiving countries to different degrees. Theoretically, this means the decision to migrate is based on a careful, rational assessment.

The Levin Institute (2011) sees push factors as negative aspects of sending countries and pull factors as positive aspects of destination/receiving countries and the two as opposite sides of the same coin. Thus, migrants not only see lack of benefits in their home countries, but also abundance of benefits and opportunities in destination/ receiving countries. According to the African Union (2006), migration is driven by a complex combination of economic push factors:

poor socio-economic conditions, low wages, high levels of unemployment, poverty and lack of opportunity are the main economic factors resulting from a mismatch between rapid population growth and the available resources, low level of requisite technology and capacity to create employment and jobs at the origin.

Compounding these economic push factors are political push factors such as poor governance, patronage and corruption, political instability, riots, conflict and civil strife, violation of human rights and terrorism. Additionally, there are social push factors, including perceived opportunities for a better life, high income, greater security, better quality of education and health care (African Union, 2006) as well as family conflicts and the desire to be independent. South African government policies such as Affirmative Action and Broad-Based Black Economic Empowerment are perceived as excluding the white population socially and economically and result in emigration (Crush, McDonald and William, 2000). According to the African Union (2006), socio-economic, political and social factors are aided by intervening factors such as relatively low cost of migration, improved communication, readily available information and the need to join a network of family and friends. 
Human-induced or natural-occurring environmental push factors such as destruction of arable and grazing land owing to bad farming practices and natural-occurring environmental push factors include avalanches, drought, earthquakes, floods, forest fires, hurricanes, landslides and volcanic eruptions may also induce migration (Levin Institute, 2011).

The 'push-pull' factor theory, which works at both macro - and micro-economic levels, dominated migration thinking into the 1960s (King, 2012). At the macro-level, it explains why labour tends to move from economies with abundant labour, but scarce capital, to those with abundant capital and high wages. At the micro-economic level, it is clear that individuals, as rational actors, weigh the advantages and disadvantages of migrating and staying as part of their decision-making process.

\section{Hypothesis of Mobility Transition}

The statement: "there are definite patterned regularities in the growth of personal mobility through space-time during recent history, and these regularities comprise an essential component of the modernization process" (Zelinsky, 1971:221-222) reflects the 'hypothesis of mobility transition'. This hypothesis provides an explanation for the nexus between changes in migration and mobility behaviour and different stages in the process of modernisation.

\section{Historical-Structural Models}

Models under this rubric are Marxist-based interpretations of capitalism and the world's structure, which are more relevant to international migration. Historical - structural models attribute international migration to "historically formed macro - structural forces, and stress the inherently exploitative and disequilibrating nature of the economic power shaping global capitalism" (Morawska, 2012:55).

\section{Dual and Segmented Labour Markets Theory}

Piore (1979) dismisses push and pull factors as causes of migration and offers a different explanation: in developed countries there is a primary labour market, which offers of secure, well-paid jobs for native workers and a secondary labour market that offers low-skill, low-wage, insecure and generally unpleasant jobs in factories and the service sector. This market mainly employs migrant workers because the jobs on offer are unacceptable to local workers. Migrant workers, particularly the undocumented, who have no bargaining power, fill the gap in the secondary-labour market, which tends to be segmented on the basis of gender, race or nationality. Employers and employment agents recruit early migrants into the segmented labour market, which is then perpetuated by 
immigrant networks (King, 2012). Employers are able to keep driving down wages in the secondary sector because migrant workers are in large supply, have no bargaining power and prefer low wages to poverty and unemployment in their home countries.

\section{Dependency Theory}

Opposed to the neoclassical paradigm, the core argument in dependency theory is that migration is self-perpetuating and reproduces inequality through cumulative causation (Myrdal, 1957; Petras, 1981). Dependency theory also runs counter to the developmentalist perspective since it does not positively associate international migration with development. According to the theory, international migration is regarded as an aspect of global division of labour and the capture of developing economies in the web of capitalist economies. This upsets the traditional lives of people in poor countries, leading people to either internal movement rural-urban migration or international migration in order to survive (King, 2012).

\section{World Systems Theory}

The world systems theory links international migration to the pre-existence of infrastructural, neo-colonial and corporate capital links between former colonial powers and their colonies. This creates "transport and communication infrastructures, administrative links, and linguistic and cultural commonalities" (Morawska, 2007:3).

In Wallerstein's (1974) conception of the theory, 'peripheral' (poor countries) depend on 'core' countries (dominant capitalist powers) such as North America, Europe, Japan, Australia and New Zealand because of unequal trading relations, capital penetration and migration.

A common weakness of historical-structural models of migration is their treatment of migrants as passive pawns in the hands of powerful capitalist countries, which ignores the fact that migration is a spontaneous phenomenon (King, 2012). Further, these models ignore the fact that migration cannot be attributed solely to capital penetration as this ignores spontaneity. Additionally, the models fail to sufficiently account for the role of states in controlling migratory movements. The political economy model acknowledges the critical role of the state in migration.

\section{Political Economy Model}

This model sees a combination of labour-demand theory and the state's political mechanisms as serving to control international migration in that migration policies of destination countries play a decisive role in determining the volume, dynamics and patterns of migratory movements (King, 2012). Morawska's (2007) hegemonic stability 
model argues that the politically and militarily powerful countries control global trade, finance and migration.

\section{Systems and Networks}

The systems approach to migration is rooted in general systems theory and enables "multiple analytical focus on structure, linkage and process" (King, 2012:20). Its flexibility enables different scales of migration such as village migration systems, interurban migration, European labour migration system, 'apartheid migration system', 'Gulf migration system' and global migration system to be studied. Since systems are self-feeding, self-regulating and self-modifying, the strength of this approach lies in its ability to move migration studies from "... a linear, unidirectional, push-pull movement to an emphasis on migration as circular, multi-causal and interdependent, with the effects of change in one part of the system being traceable through the rest of the system" (Faist, 1997:193). However, this approach is difficult to fully apply because it lacks data and research design. It is said to be mechanistic, positivist and fails to take personal and human issues into account.

Migrant networks are social ties such as kinships, friendships and common origins linking migrants, non-migrants and former migrants globally. Migrant networks are of three types: family and personal networks, labour networks and undocumented migrant networks (Boyd \& Nowak, 2012). According to Massey, Arango, Hugo, Kouaouci, Pellegrino and Taylor (1998), networks play a vital role in facilitating international migration by serving as channels for information on costs and risks of migration. Other functions networks perform include: providing information on destinations where accommodation, jobs, financial assistance and other forms of support are available (King, 2012).

Arango (2004) argues that networks offer important explanatory factors for international migration. They stand at the meso-level between micro- and macroexplanations of migration by offering individual and social-structural explanations for migration that counter 'push-pull' theories. Networks are helpful in improving understanding on differential migration, predicting future migration and distinguishing between the original causes of migration, its continuation and diffusion (King, 2012). Granovetter's (1973) 'strength of weak ties' postulates that even among vulnerable migrants, mutual trust and empathy exist, which forms bonds and leads to offers of help. Although networks are useful, they may be exclusionary, dissipate or facilitate smuggling and trafficking (King, 2012). 


\section{New Economics of Labour Migration Theory}

Stark (1991), Lucas and Stark (1985) and Stark and Bloom (1985) are the leading proponents of New Economics of Labour Migration (NELM) theory, which brings two innovative aspects to migration theory. First, it locates migration decision-making within households, not individuals, and may even involve extended families and communal groups (Massey et al., 1998). Secondly, rational choice decisions are not merely about maximising wages and income. The desire to diversify income and avoid risk is equally important, especially for families in poor sending countries that are prone to market failure and must find ways to compensate. Consequently, families and households engage in risk aversion strategies by diversifying their portfolio of income-earning and livelihood resources. NELM theory has been criticised for focusing on the supply side of labour migration; its inapplicability to poor, rural settings and to situations where whole families migrate; and the assumption that families are harmonious entities capable of making unanimous decisions (King, 2012).

As this section has shown, there are various hypotheses and theories on migration. Evidently, then, this ubiquitous phenomenon cannot be explained by a single hypothesis or theory. The next section examines South Africans' attitudes towards migrants and migration.

\section{Attitudes Towards Migration and Migrants}

Immigrants to South Africa may be broadly grouped into three: legal, regular or documented; illegal, irregular or undocumented and skilled, professional, semi-skilled or unskilled. Documented and undocumented migrants could be skilled/professional, semi-skilled or unskilled, although semi-skilled and unskilled migrants tend to be undocumented. Documented migrants are either permanent residents or people holding a relevant temporary permit such as that of a business-person, visitor, worker, refugee, student and others (Statistics South Africa, 2012). While it is possible to establish the number of documented migrants, it is very difficult to ascertain the number of undocumented migrants because this category includes 'border-jumpers' (people who manage to enter the country without any valid documentation) and those who enter legally, but neither leave when their time is up nor renew their permits. Asylum-seekers are undocumented migrants until they obtain temporary or permanent refugee permits. In this article, 'documented' and 'undocumented' are preferred to 'legal' and 'illegal' because of pejorative connotations associated with the latter terms.

South Africans are strongly opposed to migration. According to Mattes, Taylor, McDonald, Poore and Richmond (1999), a Southern African Migration Project (SAMP, 1997) national survey found that only $6 \%$ supported a totally open migration policy, $17 \%$ 
supported a flexible migration system aligned to availability of jobs, $45 \%$ wanted strict limits on migrants and migration and $25 \%$ supported the idea of banning migrating into the country. Three main issues stood out from this study. First, Mattes et al. (1999) indicate that while opposition to migration was widespread, cutting across different racial groups, income, age and educational levels, Africans and Asians showed the most restrictive attitudes. Secondly, between 1997 and 1999, support for total prohibition of migration increased from $16 \%$ to $25 \%$, with a corresponding decrease in support for a flexible approach to migration based on jobs' availability from $27 \%$ to $19 \%$ (Mattes et al., 1999). Thirdly, compared other migration destination countries for which data was available, South Africans were the most hostile to migration (Mattes et al., 1999).

\section{Attitudes Towards Migration Issues}

The SAMP (1997) national survey also examined attitudes towards four specific migration policy issues: deportation of undocumented migrants, granting of amnesty to undocumented migrants, preferential treatment for specific categories of migrants and non-citizens rights. On deportation, opposition was minimal (4\%). About half of the respondents supported it for foreigners engaged in 'illegal' activity. Specifically, 32\% favoured deportation of migrants without official permits and $17 \%$ for migrants engaged in criminal activities. Seventeen percent also supported it for migrants who do not contribute to the economy, while 21\% supported deportation of non-citizens (Mattes et al., 1999).

Amnesty for undocumented migrants was supported by $14 \%$, while $59 \%$ opposed it. Seventeen percent neither supported nor opposed it and $9 \%$ had no opinion on the issue. However, blacks (18\%) supported it more than other racial groups (4\%-6\%) (Mattes et al., 1999).

On preferential treatment of migrants for economic reasons, according to Mattes et al. (1999:12), 63\% of citizens favoured a policy for skilled workers' migration, 50\% for migrants with mining contracts and $34 \%$ for refugees. On preferential treatment based on the origin of migrants, 31\% favoured migrants from Europe and North America, 27\% migrants from Southern African countries and $22 \%$ non-SADC migrants. Compared to other racial groups, black South Africans expressed more readiness for concessions to be granted to miners and skilled workers, the economy being their main concern, but were unwilling to accept African foreigners. Conversely, with a focus on place of origin, whites preferred migrants from Europe and North America, but were less willing to accept refugees. Black South Africans also preferred European and North American migrants to African migrants (Mattes et al., 1999). 
Regarding the granting legal rights to resident non-citizens, 54\% of citizens opposed non-citizens having equal access to housing as citizens; 53\% against the right to vote and $44 \%$ against granting citizenship. Thirty-nine per cent (39\%) were opposed to granting foreign children equal access to education and medical service. Specifically, 37\% supported equal access to education, while $39 \%$ opposed it. For medical service, $38 \%$ were in support, while $39 \%$ were against (Mattes et al., 1999).

\section{Attitudes Towards Migrants}

South Africans also have a negative attitude towards migrants. Over the years, the presence of African migrants has resulted in two major xenophobic attacks (May 2008 and April 2015) and several small-scale attacks. Perceptions of and attitudes towards African migrants are negative, creating 'us and them' dichotomy, possibly because of South Africans' desire to protect socio-economic benefits accruing from the attainment of majority rule. Irrespective of legal status and skills level, with the prevailing high level of unemployment, South Africans perceive migrants as exacerbating the unemployment situation, draining the country's scarce resources, being involved in criminal activities and 'stealing' their jobs

Although Mattes et al. (1999) state that $66 \%$ of South Africans either did not express their views or specifically said it was unlikely they would act against foreign nationals, 34\% said they were likely to prevent foreign nationals from staying in their neighbourhoods or running a business. Thirty-one percent were ready to prevent foreigners' children from sitting in a classroom with their children and $32 \%$ were likely to act to prevent a foreigner becoming a co-worker (Mattes at al., 1999:14). Finally, while $48 \%$ of the respondents said they would not do anything if they knew about an undocumented foreigner, $35 \%$ indicated they would report to the police, $12 \%$ to the local community association/street committee and 3\% would undertake forceful ejection. Black South Africans were most likely to engage in collective action against foreigners, irrespective of gender or educational status (Mattes et al., 1999).

According to Williams (n.d.), a survey conducted in 2006 indicated that respondents still saw foreigners as a threat to their socio-economic wellbeing. More than two - thirds said foreigners use up resources such as water, electricity and health meant for South Africans. Another two-thirds felt African migrants commit crime. Almost half (49\%) said foreigners bring diseases such as HIV into the country. In line with the SAMP (1997) survey, in 2006 foreigners were seen as having a negative impact on the country. Further hardening of attitudes also showed more respondents saying foreigners use resources intended for citizens. 
To sum up, the SAMP (1997) national survey, the most comprehensive conducted to assist in formulating post-apartheid migration policy, is authoritative and provides an in-depth understanding of 'us and them' attitude towards migrants. It indicated South Africans dislike all non-citizens, irrespective of where they come from or their legal status. The most disliked are undocumented migrants, while migrants from Europe and North America are the least disliked (Mattes et al., 1999). South Africans also want restrictive migration policies and restrictions to migrants' rights.

\section{Socio-Economic Impacts of Migration}

The SAMP (1997) national survey indicated that South Africans believe migration has a negative impact on the country's socio-economic condition (Mattes et al., 1999). African migrants are thought to have several negative impacts and also present threats. Although a minority of South Africans (18\%) thought migrants make society stronger, majority (60\%) did not (Mattes et al., 1999). Thirty per cent (30\%) believed migrants come with valuable skills, but $43 \%$ disagreed. Twenty per cent) (20\%) thought migrants make the country's economy stronger, 59\% did not. Sixty-one per cent (61\%) thought migrants exacerbate the strain on the country's resources, $19 \%$ disagreed. South Africans' fears of foreigners hinged primarily on three key issues: crime (48\%), jobs or the economy (38\%) and diseases, particularly HIV and sexually transmitted diseases (29\%). Minor sources of fears were competition for housing (3\%), the country being overrun (2\%) and cultural and linguistic differences (1\%).

\section{Negative Impacts}

Empirical studies indicate that undocumented, semi-skilled and unskilled migrants impact on South Africa negatively in areas such as provision of social services, wage levels and employment opportunities, crime, health and poverty alleviation. Undocumented migration is detrimental to South Africa as it increases costs on social spending by exerting pressure on expenditure for social services such as education, health and housing facilities (Hussein, 2000; Hanson 2007).

Undocumented, semi-skilled and unskilled migrants' acceptance of low wages and lack of bargaining power drives down wage levels and reduces employment opportunities for South Africans (Chiranga, 2013). Employers, particularly farm owners near borders, prefer hiring undocumented migrants because they can be exploited through very low wages (R300 a week), but work long hours (up to 50 hours a week) (Bloch, 2008) without any consequences because they risk arrest and deportation if they report to authorities. This situation also applies to the hospitality industry (Hussein, 2000). Undocumented, semi-skilled and unskilled migrants' acceptance of low wages drives down wage levels and reduces employment opportunities for South Africans (Chiranga, 2013). These 
categories of migrants are also employed in the construction industry, while the domestic work market has significant numbers of undocumented, semi-skilled and unskilled female Zimbabwean and Mozambican employees. It is claimed that in 19992000 the informal trading sector had 500 ooo undocumented migrants traders who were evading import duties and selling products cheaper than their local counterparts, thereby out-competing them (Chiranga, 2013).

Regarding crime, Danso and McDonald (2000) acknowledge increased involvement of migrants in crime, but there is no evidence suggesting foreigners are disproportionately involved in criminal activities (Landau \& Segatti, 2009). Hussein (2000) notes the existence of anecdotal evidence suggesting a nexus between undocumented migrants and criminal activities such as armed robbery, drug trafficking and money laundering. According to Hussein (1996), undocumented migrants were implicated in $14 \%$ of crimes committed. The author also avers that in 1996, 152 migrants were involved in commercial crime valued at R518 million, which represented $19.6 \%$ of commercial crimes at the time.

Crimes migrants are allegedly involved include illegal telegraphic fund transfers, popularly known as '419', making counterfeit identity documents for sale to other migrants and using fake identity documents to buy furniture on credit (Hussein, 2000). Lube (2008) is of the view that although migrants commit crimes, the level of their involvement is exaggerated. As migration involves mobility, it facilitates conscious or unconscious spreading of communicable diseases, including sexually - transmitted diseases, human immune-deficiency virus (HIV) and acquired immune-deficiency syndrome (AIDS) and tuberculosis. Migrants suffering from diseases who seek treatment put strain on the health system, while those who hide their illnesses because they lack proper documentation (Hussein, 2000) and fear repatriation expose other people to serious health risks. Carael, Cleland, Feery and Ingham (1995) claim that migrants facilitate quick spread of sexually transmitted and other diseases.

\section{Positive Impacts}

South Africa faces scarce and critical skills crisis. To address this, the Accelerated and Shared Growth Initiative for South Africa (ASGISA) and Joint Initiative on Priority Skills Acquisition (JIPSA) were rolled out in 2005 and 2006, respectively. According to Daniels (2007), in February 2006 the Department of Home Affairs identified 'scarce and critical skills' essential for South Africa's economic growth, making migration easier for foreigners. This led to semi - to highly-qualified skilled African migrants such as doctors, engineers and other professionals migrating to South Africa. In the mid-199os, economic, social and political crisis in African countries such as Zaire, Nigeria, Somalia, Senegal, Congo and Zimbabwe, led to forced migration to South Africa (Morris \& Bouillon, 2001), including African elites such as academics, teachers, bankers, 
consultants and journalists (Landau \& Kabwe-Segatti, 2009). Apart from providing scarce skills, migrants are also known to have helped South African businesses to open up markets in the country and elsewhere (Morris \& Bouillon, 2001). Crush (2000) states that skilled migrants "create enterprises and jobs for locals, they enhance the productivity of existing enterprises and they pass on valuable skills and experience". South Africa has experienced 'brain gain' from experienced, skilled, professional, highly-qualified African migrants, most of whom are trained at great expense by their respective countries and little or no cost to South Africa, who fill vacancies created by emigration of South Africans to Europe, North America, Australia and New Zealand. In the higher education and public health sectors, South Africa benefits immensely from experienced and professionally-qualified African migrants, while skilled and semi-skilled African migrants' positive impacts are felt in the private sector through entrepreneurship and job creation.

\section{Higher Education Sector}

Phiri (2010), citing the South African Ministry of Education Department of Higher Education 2010 Annual Report, indicates the headcount of immigrant instruction/ research professionals permanently appointed at South African universities between 2005 and 2009 as $7.35 \%$ in $2005,7.82 \%$ in $2006 ; 8.78 \%$ in $2007,8.25 \%$ in 2008 and $9.03 \%$ in 2009.

Of 1124 immigrant instruction/research professionals in South African universities in 2005, Europe had the most, 229 professionals (1.5\%). Among Southern African countries, Zimbabwe contributed 116 professionals, of whom more than $10 \%$ were employed at rural universities. For other Southern African countries the figures were: Swaziland, 8; Malawi, 16; Botswana, 6; Lesotho, 4.The rest of Africa accounted for 167 professionals. Beneficiaries of services offered by these professionals were rural universities such as University of Venda, University of Limpopo, University of Zululand and North West University.

In 2006, Europe and Asian countries had 315 (1.99\%) and 43 (0.27\%) professionals in South African universities, respectively, while Zimbabwean professionals stood at $134(0.85 \%)$. Again, most of these professionals were employed at rural universities, including University of Zululand, University of Limpopo, North West University and University of Venda.

Europe still had the highest number of immigrant instruction/research professionals (383), representing 2.35\% in South African universities in 2007, while Asian countries had 76 (0.47\%). Figures for Southern African countries were: Zimbabwe, 237 (1.49\%); Zambia, 41 (o.26\%); Botswana, 20; Malawi, 19 (0.12\%); Lesotho, 12 (o.12\%); Swaziland, 7 
and the rest of Africa 259 (1.64\%). Fifty-five of these professionals were working in rural universities.

In 2008, the number of instruction/research professionals in South African universities from the rest of Africa increased from to 307 from 259 in 2007. Instruction/research professionals from Zimbabwe increased from 166 to 267, Botswana realised an increase of two, from 13 in 2007 to 15, but Zambia's instruction/research professionals decreased from 41 to 36 .

Finally, in 2009, 383 (2.35\%) European and 76 (0.47\%) Asian immigrant instruction/ research professionals were employed in South African universities. Zimbabwe and Lesotho accounted for 268 (1.64\%) and 26 (0.16\%) instruction/research professionals, respectively, while the rest of Africa contributed 324 (1.99\%). Table 1 shows the percentages of immigrant instruction/research professionals in South African universities for the period 2005 to 2009.

Table 1: Percentage headcount of instruction/research professionals with permanent appointments in South African public universities: 2005 to 2009

\begin{tabular}{|l|l|l|l|l|l|}
\hline & 2005 & 2006 & 2007 & 2008 & 2009 \\
\hline $\begin{array}{l}\text { European } \\
\text { countries }\end{array}$ & $1.50 \%$ & $1.99 \%$ & $2.18 \%$ & $2.32 \%$ & $2.35 \%$ \\
\hline Asian countries & $0.22 \%$ & $0,27 \%$ & $0.30 \%$ & $0.41 \%$ & $0.47 \%$ \\
\hline $\begin{array}{l}\text { Other African } \\
\text { countries }\end{array}$ & $1.09 \%$ & $1.47 \%$ & $1.64 \%$ & $1.93 \%$ & $1.99 \%$ \\
\hline Botswana & $0.04 \%$ & $0.04 \%$ & $0.08 \%$ & $0.09 \%$ & $0.14 \%$ \\
\hline Lesotho & $0.03 \%$ & $0.05 \%$ & $0.08 \%$ & $0.11 \%$ & $0.16 \%$ \\
\hline Malawi & $0.10 \%$ & $0.11 \%$ & $0.12 \%$ & $0.14 \%$ & $0.14 \%$ \\
\hline Zambia & $0.20 \%$ & $0.25 \%$ & $0.26 \%$ & $-0.23 \%$ & $0.23 \%$ \\
\hline Zimbabwe & $0.76 \%$ & $0.85 \%$ & $1.05 \%$ & $1.49 \%$ & $1.64 \%$ \\
\hline
\end{tabular}

Source: Phiri (2010:34)

\section{Public Health Sector}

South African economy is negatively affected by 'brain drain' or skills flight of professional health personnel to Europe, United States of America and Australia (Landau \& Kabwe-Segatti, 2009). Phiri (2010), citing MEDICC Review (2008), notes that in 2005 there were about 46 ooo vacant professional health workers posts in the public sector. The author found that vacancies created by movement of South African health personnel from rural areas and poor provinces to urban areas and well-resourced provinces or emigration to Europe, North America, Australia and New Zealand are filled by migrant doctors. Cooke, Couper and Versteeg (2011:108) state that 30\% per cent of South 
African doctors and $15.5 \%$ of pharmacists are employed in the public sector, but a small proportion of them are serving in rural areas, where $43 \%$ of the population resides. Table 2 shows provincial distribution and top three countries of origin of foreign medical practitioners, dentists and pharmacists, an indication African countries are playing an important role in alleviating the shortage of medical personnel in the public health system. According to Segatti (2014:29), overall foreign personnel constitute 1.5\% (2 650 out of 173 080) of the public health workforce. Profession-wise, 67\% (1 760) of foreign public health personnel are medical practitioners, $14 \%$ (370) medical specialists, $7 \%$ (190) nursing professionals, $5 \%$ (140) pharmacists, $4 \%$ (100) other health professionals and associate professionals, $1 \%$ dentists (40), 1\% (20) nursing assistants and $1 \%(20)$ other qualified occupations (Segatti, 2014:30). Thirty-eight per cent (38\%) of foreign medical practitioners, specialists, dentists or pharmacists are from SADC countries, $26 \%$ from the rest of Africa and 36\% from elsewhere in the world (Segatti, 2014:31). Of the top ten countries foreign medical practitioners, medical specialists, dentists and pharmacists originate, seven are African: Democratic Republic of Congo (490), Nigeria (380), Zimbabwe (150), Lesotho (60), Botswana (60), Tunisia (50) and Uganda (50) (Segatti, 2014:32). Table 2 shows the provincial distribution of foreign medical practitioners, dentists and pharmacists. 
Table 2: Provincial distribution and top three countries of origin of foreign medical practitioners, dentists and pharmacists

\begin{tabular}{|c|c|c|c|}
\hline Province & $\begin{array}{l}\text { Number of health } \\
\text { professionals }\end{array}$ & Countries of origin & Percentage \\
\hline Gauteng & 590 & $\begin{array}{l}\text { DRC } \\
\text { Nigeria } \\
\text { Zimbabwe }\end{array}$ & $\begin{array}{l}36 \\
12 \\
8\end{array}$ \\
\hline KwaZulu-Natal & 510 & $\begin{array}{l}\text { Nigeria } \\
\text { DRC } \\
\text { United Kingdom }\end{array}$ & $\begin{array}{l}15 \\
13 \\
13\end{array}$ \\
\hline Eastern Cape & 310 & $\begin{array}{l}\text { Nigeria } \\
\text { India } \\
\text { Cuba }\end{array}$ & $\begin{array}{c}25 \\
14 \\
9 \\
\end{array}$ \\
\hline North West & 200 & $\begin{array}{l}\text { DRC } \\
\text { Botswana } \\
\text { Nigeria }\end{array}$ & $\begin{array}{l}25 \\
12 \\
11\end{array}$ \\
\hline Western Cape & 170 & $\begin{array}{l}\text { United Kingdom } \\
\text { DRC } \\
\text { Cuba }\end{array}$ & $\begin{array}{l}31 \\
12 \\
7 \\
\end{array}$ \\
\hline Mpumalanga & 170 & $\begin{array}{l}\text { Nigeria } \\
\text { DRC } \\
\text { Cuba }\end{array}$ & $\begin{array}{l}31 \\
12 \\
7\end{array}$ \\
\hline Limpopo & 150 & $\begin{array}{l}\text { Nigeria } \\
\text { Cuba } \\
\text { DRC }\end{array}$ & $\begin{array}{l}23 \\
17 \\
12\end{array}$ \\
\hline Free State & 140 & $\begin{array}{l}\text { DRC } \\
\text { Lesotho } \\
\text { Nigeria }\end{array}$ & $\begin{array}{c}41 \\
17 \\
8 \\
\end{array}$ \\
\hline Northern Cape & 70 & $\begin{array}{l}\text { Cuba } \\
\text { DRC } \\
\text { Nigeria }\end{array}$ & $\begin{array}{l}27 \\
21 \\
13\end{array}$ \\
\hline
\end{tabular}

Segatti (2014:33-34)

\section{Entrepreneurship and Job Creation}

Phiri (2010) cites Statistics South Africa (2003) as acknowledging that skilled personnel from neighbouring countries play an important role in creating employment. Small business development and entrepreneurship is the life-blood of every economy. Difficulties in obtaining formal employment in the public and private sectors has led to African migrants becoming increasingly active in establishing their own businesses. Rogerson's (1999) study of foreign-owned small-, medium - and micro-enterprises 
(SMMEs) in Johannesburg found that these enterprises play a significant role in changing the city's landscape and economy. Table 3 shows various entrepreneurial activities foreign-owned SMMEs are engaged in.

Table 3: Migrants' business clusters according to their origins

\begin{tabular}{|c|c|c|}
\hline Sector & Activity & Origin of immigrant \\
\hline \multirow[t]{3}{*}{ Retail } & Curio selling & Malawi, Mozambique \& Zimbabwe \\
\hline & Selling ethnic clothing & West Africa \\
\hline & Food retail & West Africa \\
\hline \multirow[t]{3}{*}{ Service } & Motor car repairs/panel beating & Mozambique \& Zimbabwe \\
\hline & Hairdressing & All \\
\hline & Operating restaurants & West Africa \\
\hline \multirow[t]{3}{*}{ Production } & Traditional clothing & West Africa \\
\hline & Wedding dresses & West Africa \\
\hline & General tailoring & Malawi \\
\hline \multirow[t]{5}{*}{ Other business sectors } & Nightclubs & West Africa \\
\hline & Cafes & West Africa \\
\hline & Import/export & West Africa \\
\hline & Music shops & Central Africa, West Africa \\
\hline & Traditional healing & East Africa, West Africa \\
\hline
\end{tabular}

Source: Kalitanyi and Visser (2010:379)

Rogerson (1999) also found distinct differences between SMMEs operated by migrants from the SADC and those of their non-SADC operators regarding international linkages, sources of start-up finance, size and diversity and educational backgrounds of the entrepreneurs as depicted in Table 4. 
Table 4: Differences between SADC - and non-SADC migrants' operated SMMEs

\begin{tabular}{|l|l|}
\hline SADC migrant entrepreneurs & Non-SADC migrant entrepreneurs \\
\hline $\begin{array}{l}\text { Do not have international ties; seldom } \\
\text { maintain contact with compatriots at home } \\
\text { regarding business opportunities and } \\
\text { possibilities of expansion }\end{array}$ & $\begin{array}{l}\text { Have integrated businesses supported by wider } \\
\text { international and regional (SADC) migrant networks. } \\
\text { Fifty-six per cent (56\%) of the sample had operated } \\
\text { similar businesses in their home countries. They have } \\
\text { a wide international family and business connections, } \\
\text { including links with West Africa, Canada, the USA and } \\
\text { Europe. }\end{array}$ \\
\hline $\begin{array}{l}\text { Most start-up capital derived from savings } \\
\text { from previous jobs in South Africa. }\end{array}$ & $\begin{array}{l}\text { Finance mostly derives from funds brought in from } \\
\text { outside South Africa. }\end{array}$ \\
\hline $\begin{array}{l}\text { Their businesses are smaller and seemingly less } \\
\text { well-capitalised than those of their non-SADC } \\
\text { counterparts. }\end{array}$ & $\begin{array}{l}\text { The diversity and strength of their businesses } \\
\text { derives from exploiting income niches such as 'ethnic } \\
\text { businesses' and those of Francophone culture. }\end{array}$ \\
\hline Majority had a secondary school education. & $\begin{array}{l}\text { Better educated, about 50\% have some university } \\
\text { education, which gives them wider horizons in their } \\
\text { business development strategies. Three had masters' } \\
\text { degrees and one was a qualified dentist. }\end{array}$ \\
\hline
\end{tabular}

Source: Kalitanyi and Visser (2010:380, adapted from Rogerson, 1999)

Timberg (2005) dispels the view that foreigners steal jobs by asserting that, in fact, they create employment for themselves and, sometimes, for unemployed South Africans. Kalitanyi and Visser's (2010) study to ascertain whether African migrants steal jobs from South Africans or create their own was based on data from 120 migrant entrepreneurs running businesses in Bellville, Cape Town's Foreshore, Nyanga and Wynberg and seven organisations providing services, advice and support to migrants based in Cape Town. The study found that $31 \%$ of the entrepreneurs had a Technikon, Bachelor's or postgraduate degree, while $69 \%$ had primary and high school qualifications. Faced with difficulties in gaining employment, they had created employment not only for themselves, but also for other migrants and unemployed South Africans. In fact, eightytwo percent of the migrant entrepreneurs employed South Africans.

\section{Recommendations}

Migration is instrumental in facilitating development. The African Union is working towards removing barriers to free movement of people and goods across national borders. Given the South African government's emphasis on 'scarce and critical skills' for national development, governance of migration needs to be guided by the country's human resource needs. Implementation of the following recommendations could assist in harnessing the potential of migrants for the country's development: 
- Address xenophobia by eradicating 'us and them' thinking through continuous education to disabuse many South Africans of stereotypical attitudes and prejudices against African migrants.

- $\quad$ Engage governments of major migrant-producing SADC countries with a view to finding win-win solutions to reducing undocumented migration and securing the country's borders.

- $\quad$ Adopt a development-oriented migration policy that identifies specific categories of African migrants as human capital assets and provides for expeditious recruitment processes.

\section{Conclusion}

While the negative perception of African migrants is widespread, their positive socioeconomic impacts on South Africa cannot be ignored. Nevertheless, few South Africans recognize positive impacts made by migrant African academics, medical personnel and entrepreneurs have on the country's development. African migrants contribute immensely to national development. Professionally-qualified, experienced and skilled migrants fill critical gaps in the formal labour market created by emigration of South Africans to Europe, North America, Australia and New Zealand, while their semi-skilled/ unskilled counterparts either provide invaluable services in the informal labour market or establish their own job-creating business enterprises. In the higher education and training sector, migrant African intellectuals in rural and urban universities, especially in the former that struggle to attract local academics, contribute to developing highlevel human resources for the knowledge economy. Further, the public health system in rural settings, in particular, is kept going through services provided by African and other migrant medical personnel. With poverty, unemployment and inequality rife in the country and exacerbated by many citizens' lack of skills and consequent unemployability in the formal sector, entrepreneurship is the future lifeblood of the economy. African migrants have established small business enterprises that create employment opportunities for themselves and South Africans citizens and open up hitherto nonexisting markets. Consciously or inadvertently, African entrepreneurs serve as models of business success to budding South African entrepreneurs in the informal sector. In spite of low wages, semi-skilled/unskilled African migrants provide services in the agricultural, construction and domestic services sectors. Governance of migration, through the adoption of a development-oriented policy, could assist in the country's 'scarce and critical skills' shortage and harness migrants' skills to facilitate development. 


\section{References}

African Union. (2006). The migration policy framework for Africa. Executive Council, Ninth Ordinary Session. 25-29 June 2006. Banjul, The Gambia.

Arango, J. (2004). Theories of international migration. In Joly. D. (Ed.). International migration and the new millennium. Aldershot: Ashgate, pp. 15-36.

Bakewell, 0. (2009). South-South migration and human development: reflections on African experiences. Human Development Research Paper 2009/07. New York: UN Development Programme.

Bloch, A. (2008). Gaps in protection: undocumented Zimbabwean migrants in South Africa. University of Witwatersrand Migration Studies Working Paper Series 38.

Boyd, M. and Nowak, J. (2012). Social networks and international migration. In Martiniello, M. and Rath, J. (Eds.). An introduction to international migration studies. Amsterdam: Amsterdam University Press, pp. 77-103.

Carael, M., Cleland, J., Feery, B. and Ingham, R. (1995). Sexual behaviour in developing countries: implications for HIV control. AIDS, 9(10), pp. 1171-1175. October.

Chiranga, V. (2013). The effects of immigration in contemporary South Africa. Dissertation submitted in partial fulfilment of the requirements for the degree Magister Technologiae: Comparative Local Development, Department of Finance, Faculty of Economics and Finance, Tshwane University of Technology.

Cooke, R., Couper, I. and Versteeg, M. (2014). Human resources for rural health. South African Health Review (SAHR) 2011. 108-118.

Couper, I.D. (2003). Recruiting foreign doctors to South Africa: difficulties and dilemmas. Rural and Remote Health 3 online. The International Electronic Journal of Rural and Remote Health Research, Education, Practice and Policy. http://www.wits. ac.za/media/migration/files/articleprint195.pdf [25 September 2016]

Crush, J., McDonald, D. and William, V. (2000). Losing our minds: skills migration and the South African brain drain. Southern African Migration Project. Migration Policy Series No. 8.

Daniels, R. (2007). Skills shortages in South Africa: a literature review. University of Cape Town Development Policy Research Unit, Working Paper. May 2007. [25 September 2016].

Danso, R. and McDonald, D.A. (2000). Writing xenophobia: immigration and the press in post-apartheid South Africa. Africa Today, 48(3), pp. 115-137. 
Dutch Ministry of Foreign Affairs. (2008). International Migration and Development. Policy Memorandum. The Hague: Policy Department Movement of Persons, Migration and Alien Affairs Department.

Faist, T. (1997). The crucial meso-level. In Hammar, T., Brochmann, G., Tamas. K. and Faist, T. (Eds.). International migration, immobility and development: multidisciplinary perspectives. Oxford: Berg, pp. 187-218.

Global Forum on Migration and Development. (2012). Rapporteur's Report to Round Table 2.2: Addressing South-South Migration and Development Policies, GFMD Mauritius 2012.http://www.gfmd.org/documents/mauritius/gfmd_mauritius12_ rapporteurs_report_rt2.pdf. [24 September 2016]

Granovetter, M.S. (1973). The strength of weak ties. American Journal of Sociology, 78(6), pp. $1360-1380$.

Haas, H. (2010). Migration and development: a theoretical perspective. International Migration Review, 44(1), pp. 227-264.

Hanson, G.H. (2007). The economic logic of illegal immigration. Council on Foreign Relations. The Bernard and Irene Schwartz Series on American Competitiveness. Council Special Report No. 26.

Hussein, S. (1996). Strategic perspectives in illegal immigration in South Africa. African Security Review, 5(4), pp. 3-15.

Hussein, S. (2000). Contemplating the impact of illegal immigration on the Republic of South Africa. Unit for African Studies Working Paper. Centre for International Political Studies. University of Pretoria. http://www.queensu.ca/samp/ sampresources/migrationdocuments/documents/200o/ solomon.htm [20 September 2016].

International Organisation for Migration (IOM). (2013). Migration and development within the South: new evidence from African, Caribbean and Pacific countries. Migration Series No 46. IOM: Geneva.

Kalitanyi, V. and Visser, K. (2010). African immigrants in South Africa: job takers or job creators? South African Journal of Economic and Management Sciences, NS 13(4), pp. 376-390.

King, R. (2012). Theories and typologies of migration: an overview and primer. Willy Brandt series of Working Papers in International Migration and Ethnic Relations 3/12. Malmo Institute for Studies of Migration, Diversity and Welfare (MIM). Malmo University. https:/www.mah.se/upload/Forskningscentrum/MIM/WB/ WB\%203.12.pdf [25 September 2016] 
Landau, R. and Segatti, A.K. (2009). Human development impacts of migration: South African case study. United Nations Development Programme Human Development Research Paper (HDRP) Series, Research Paper 2009/5.

Levin Institute. (2011). Migration and globalization. http://www.globalization101.org/ uploads/File/Migration/migration2011.pdf [24 September 2016].

Lube, G. (2008). Victims of xenophobia: African immigrants in South Africa http://www. desmondtutudiversitytrust.org.za/xenophobia.pdf [25 September 2016].

Lucas, R.E.B. and Stark, O. (1985). Motivations to remit: evidence from Botswana. Journal of Political Economy, 93(5), pp. 901-918.

Maja, Botshabelo and Nakanyane, Sabata. (2007). Labour migration and South: Africa: towards a fairer deal for migrants in the South African economy. Labour Market Review 2007. Pretoria: Department of Labour.

Malmberg, G. (1997). Time and space in international migration. In Hammar, T., Brochmann, G., Tamas, K. and Faist, T. (Eds.). International migration, immobility and development: multidisciplinary perspectives, Oxford: Berg, pp. 21-48.

Massey, D.S., Arango, J, Hugo, G., Kouaouci, A., Pellegrino, A. and Taylor, E.T. (1993). Theories of international migration: a review and appraisal. Population and Development Review, 26(3), pp. 431-466.

Massey, D.S., Arango, J., Hugo, G., Kouaouci, A., Pellegrino, A. and Taylor, J. E. (1998). Worlds in motion: understanding international migration at the end of the millennium. Oxford: Clarendon Press.

Mattes, R., Taylor, D.M, McDonald, D.A., Poore, A. and Richmond, W. (1999). Still waiting for the barbarians: SA attitudes to immigrants and immigration. Southern African Migration Project. Idasa: Cape Town and Queen's University, Canada.

Morawska, E. (2007). International migration: its various mechanisms and different theories that try to explain it. Malmö: Malmö University, Willy Brandt Series of Working Papers in International Migration and Ethnic Relations 1/07. http://www. dspace,mah.se [24 September 2016]

Morawska, E. (2012). Historical-structural models of international migration. In Martiniello, M. and Rath, J. (Eds.). An introduction to international migration studies. Amsterdam: Amsterdam University Press, pp. 55-75.

Morris, A. and Bouillon, A. (2001). African immigration to South Africa: Francophone migration of the 1990's. First English Edition. Pretoria: Protea \& IFAS.

Myrdal, G. 1957. Rich lands and poor. New York: Harper \& Row. 
Odeh, L.E. (2010). A comparative analysis of global north and global south economies. Journal of Sustainable Development, 12(3), pp. 338-348.

Petras, E. (1981). The global labour market in the modern world economy. In Kritz, M.M., Keely, C.B. and Tomasi, S.M. (Eds.). Global trends in migration: theory and research on international population movements. New York: Center of Migration Studies, pp. 4463.

Phiri, K.E. (2010). The contribution of skilled immigrants to the South African economy since 2004: a case study of health and higher education sectors. Research report presented in partial fulfillment of the requirements for the degree of Master's Degree in Development Finance at the University of Stellenbosch. University of Stellenbosch.

Piore, M.J. (1979). Birds of passage: migrant labour and industrial societies. New York: Cambridge University Press.

Ratha, D., Mohapatra, S., Ôzden, C., Plaza, S., Shaw, W. and Shimeless, A. (2011). Leveraging migration for Africa: remittances, skills and investments. Washington, D.C.: The World Bank. Ravenstein, E.G. (1885). The laws of migration - I. Journal of the Statistical Society, 48(2), pp. 167-227.

Ravenstein, E.G. (1889). The laws of migration - II. Journal of the Statistical Society, 52(2), pp. 214-301.

Rogerson, C.M. (1999). International migration, immigrant entrepreneurs and South Africa's small enterprise economy. http://www.queensu.ca/sampresources/ samppublications/policyseries/policy3.htm. [23 September 2016].

Rystad, G. (1992). Immigration history and the future of international migration, International Migration Review, 26(4), pp. 1169-1197.

Segatti, A. (2014). A disposable workforce: foreign health professionals in the South African public service. MiWORC Report No 7. Johannesburg: African Centre for Migration and Society. University of the Witwatersrand.

Stark, O. (1991). The migration of labor. Cambridge, Mass.: Basil Blackwell. Stark, O. and Bloom, D.E. (1985). The New Economics of Labour Migration. American Economic Review, 75(2), pp. 173-178.

Statistics South Africa. (2012). Documented migrants in South Africa 2012. http:// www.statssa.gov.za/publications/Po3514/P035142012.pdf [19 September 2016]

Maja, Botshabelo and Nakanyane, Sabata. (2007). Labour migration and South: Africa: towards a fairer deal for migrants in the South African economy. Labour Market Review 2007. Pretoria: Department of Labour. 
Timberg, C. (2005). Refugees with hopes, skills find opportunity in South Africa. Washington Post Foreign Service. Sunday January 9, page A 21. Washingtonpost. com

United Nations. (1982). International migration policies and programmes: a world survey. New York, NY: United Nations.

Wallerstein, I. (1974). The modern world-system: capitalist agriculture and the origins of the European world economy in the sixteenth century. New York: Academic Press.

williams, v. (n.d.). Xenophobia in South Africa: overview and analysis. Perspectives: political analysis and commentary from Southern Africa. Heinrich Böll Stiftung.\#3.08 https://za.boöell.org/sites/default/files/downloads/HBS_ Perspectives_03.08_Xenopho bia.pdf [19 October 2016]

Zelinsky, w. (1971). The hypothesis of the mobility transition, Geographical Review, 61(2), pp. 219-249.

Zinyama, L.M. (1990). International migration to and from Zimbabwe and the influence of political changes on population movements, 1965-1987. International Migration Review, 24(4), pp. 448-467.

Zopf, E.P. (Jr.). 1984. Population: an introduction to social demography. Mayfield Publishing Co. California: USA. 